\title{
TRANSFORMASI POLIGAMI DALAM BINGKAI SYARI'AT ISLAM DI ACEH
}

\author{
Dr. Muhammad Zukhdi, Lc, MA \\ zukhdi@gmail.com \\ Dosen STIS Ummul Ayman Pidie Jaya \\ Faisal, SHI, MA \\ faisalfasya@iainlangsa.ac.id \\ Dosen Fakultas Syariah IAIN Langsa
}

\begin{abstract}
People's views on polygamy are diverse, there are those who agree, but there are also those who disagree or oppose even more for women who feel disadvantaged, because they have to share with others. This is influenced by the family economy which does not allow polygamy. Such allegations eventually feel unsatisfied with suspection and even challenge qath'i syar'i texts with interpretations that are far from the elements of truth. So that legal issues are interpreted with multiple interpretations and cause vague and vague issues. And the Aceh which was given the authority in making qanun implementation of islamic shari'ah and participated in discussing anddesigning the Qanun (Raqan) family law which regulates polygamy but the draft qanun raises pro and contra at the people of Aceh.
\end{abstract}

Keyword: Polygamy, Islamic Sharia, Raqan

\section{Pendahuluan}

Permasalahan yang masih terjadi dikalangan masyarakat dan terjadi pro dan kontra adalah poligami. Poligami di dalam masyarakat masih dianggap sebagai perbuatan yang negatif yang dengan sebab itu maka poligami masih dianggap adalah perbuatan yang tabu dan perbuatan yang menjadi retaknya suatu bahtera rumah tangga.

Sebagaimana kita tahu bahwa tujuan hidup dalam berkeluarga adalah seperti yang ada dalam regulasi perkawinan Indonesia tahun 1974 dan juga buku KHI yakni bertujuan demi mencapai yang namanya bahagia baik lahirnya atau bathinnya. Tetapi begitu seorang suami yang adalam satu perkawinan melakukan poligami maka yang namanya bahagia yang ingin dicapai oleh satu keluarga maka akan hilang dengan sendirinya, hanya gegara poligami. Dan ini sangat disanyangkan dan sangat memberi bekas kepada sang istri dan anak-anaknya. Ini semua dkeranakan mereka 
sang istri dan anak-anaknya beranggapan bahwa mereka tidak mendapat keadilan dari suami atau ayah anak-anak mereka.

Seperti itulah pandangan dan anggapan masyarakat terhadap poligami banyak pandangan atau pendapat dari masyarakat tidak setuju akan poligami, namun tentunya ada juga yang beranggapan bahwa poligami itu adalah boleh dan dibolehkan oleh agama. Namun terlepas dari itu semua pendapat dan pandangan yang mentakan poligami adalah suatu hal yang tidak boleh adalah semuanya bermuara pada permasalahan ekonomi dimana bila dilihat dengan kasat mata tidak memungkinkan untuk dilakukan poligami oleh suaminya. Sehingga akibat yang dimunculkan adalah ketidak puasan terhadap dan rasa curiga terhadap orang-orang yang melakukan plogami dan pada akhirnya berani menentang nash-nash yang suda sangat jelas-jelasnya dikatankan bahwa hukum poligami tersebut adalah boleh.

Berbicara tentang poligami, maka terbayang akan satu daerah di dalam wilayah Indonesia yakni provinsi Aceh, yang berani membahas dan merancang sebuah qanun (Perda) hukum keluarga khususnya yang mengatur tentang poligami oleh Dewan Perwakilan Rakyat Aceh (DPRA). Beraninya provinsi Aceh membahas dan merancang sebuah qanun (Perda) dikarenakan provinsi Aceh berbeda dengan provinsi-provinsi lain yakni diberikan kewenangan penuh dalam hal pelaksanaan syariat Islam. Namun demikian, adapun hasil pembahasan tersebut tidaklah berjalan dengan mulus, dikeranakan pembahasan tentang poligami menuai adanya pro dan kontra baik dikalangan sesama anggota DPRA sendiri atau dari kalangan politisi, akademisi bahkan dari masyarakat luas.

Pada dasarnya pembahasan tersebut adalah tentang hukum Islam baik menyangkut dengan hukum keluarga, hukum muamalah, hukum jinayah (pidana) terus berkembang seiring dengan perkembangan waktu dan keadaan karena itu perlu terus dikaji dan diteliti kembali hal yang masih mempunyai ruang dan celah untuk dikaji terutama hukum yang menyangkut dengan keluarga yang masih dikaji, seperti pembatasan usia perkawinan, pencatatan nikah, nikah sirri, nikah mut'ah, qadhi liar (muhakam) dampak positif dan negative dalam kehidupan masyarakat dengan mengedepankan nilai-nilai maslahah dan menolak mafsadah (kerusakan kehancuran).

\section{Kerangka Poligami}

Dalam bahasa Yunani poligami itu adalah terdiri dari 2 kosa kata yakni polus dan gamos, artinya banyak dan perkawinan. Dengan demikian maka poligami adalah satu orang yang melakukan banyak perkawinan atau lebih sekali. Adapun perkawinan tersebut yakni perkawinan yang dilakukan oleh seorang laki-laki dengan beberapa perempuan dalam sebuah sistem maka perbuatan tersebut disebut poligami. ${ }^{1}$

Kamus bahasa Indonesia menyatakan poligami itu adalah perkawinan yang dilakukan dalam sebuah ikatan dan dilakukan dalam waktu bersamaan dengan

\footnotetext{
${ }^{1}$ Ensiklopedi Indonesia, Jilid 5, (Jakarta: Ikhtiar Baru Van Hoeve), hlm. 988.
} 
beberapa lawan jenisnya atau seseorang laki-laki yang menikah dan mempunyai beristri banyak. $^{2}$

Secara jelas dalam Islam dinyatakan bahwa poligami itu adalah ta'addud az Zaujat artinya banyak kawin dengan beberapa perempuan yakni sebanyak 2, 3 atau empat dan itupun apabila bisa berlaku adil terhdap isteri-isterinya itu. ${ }^{3}$

Maka jelaslah bahwa pemakaian kata-kata poligami tersebut adalah bagi seorang laki-laki yang punya isteri banyak atau lebih dari satu namun tidak lebih dari empat. Dan keablikannya daripadanya yaitu seorang perempuan yang punya suami lebih dari satu adalah diistilahkan dengan istilah poliandri. ${ }^{4}$

Alhasil, satu aqad yang dilakukan oleh seorang laki dengan lebih dari satu isteri dan dalam waktu yang bersamaan adalah disebut poligami, sedangkan perempuan yang mempunyai lebih dari satu suami adalah poliandri. Dan ada istilah yang lain yaitu monogami yakni aqad yang dilakukan seorang laki-laki dengan seorang perempuan dibawah naungan janji setia diantara mereka untuk sehidup semati dan dalam waktu tertentu. ${ }^{5}$

\section{Pandangan Ulama Klasik}

Adapun para ulama terdahulu dan ulama pertengahan, mereka dalam hal poligami berpendapat membolehkan praktek tersebut. Namun demikian mereka membolehkannya tetap dengan melihat kepada prosedur dan syarat-syarat dalam berpoligami, seperti boleh poligami tetapi hanya boleh empat dan harus berlaku adil.

Secara normatif keadilan adalah suatu hal yang mustahil dapat diwujudkan oleh pasangan poligami dan ini diakui oleh mayoritas ulama fiqh. Pendapat ini dengan fleksibel diakui juga oleh Abdurrahman al-Jaziri yang dikemukakannya dalam kitabnya, yakni kasih sayang dan mensamakan dalam bidang seksual diantara para isteri-isterinya adalah buakan suatu kewajiban bagi seorang laki-laki yang poligami. Karena secara fitrah dan naluriah manusia tidak akan mampu dalam berbuat adil. Dan seoarng suami pasti akan tertarik pada salah satu diantara para isteri-isterinya, apakah itu isterinya yang pertama atau isterinya yang paling muda atau yang keempat dan itu adalah sangat wajar. ${ }^{6}$

Imam Syafi'i adalah pengarang kitab "al Umm", beliau menyatakan bahwa sesuai dengan hadis Ibnu Umar tentang seorang sahabat yang bernama Gailan bin

\footnotetext{
${ }^{2}$ Departemen Pendidikan dan Kebudayaan RI., Kamus Besar Bahasa Indonesia, (Jakarta: Balai Pustaka), hlm.693. Diantara para ahli ada yang lebih dalam pemahamannya sehingga mereka membedakan laki-laki yang mempunyai banyak isteri adalah poligami sedangkan seorang perempuan yang memiliki banyak laki-laki (suami) maka dalam istilah hukum disebut poliandri.

${ }^{3}$ Achmad Kuzani, Nikah Sebagai Perikatan, (Jakarta: PT Raja Grafindo, 1995), hlm.159.

${ }^{4}$ Sohari Sahrani Tihami, Fikh Munakahat: Kajian Fiqh Nikah Lengkap. (Jakarta: Rajawali Pers, 2010). hlm. 351.

${ }^{5}$ Al qamar Hamid, Hukum Islam Alternative Terhadap Masalah Fiqh Kontemporer, (Jakarta: Restu Ilahi, 2005), hlm 19.

${ }^{6}$ Abd. al Rahman al Jazairi, al Fiqh 'ala al Madzahib al 'Arba'ah, (Mesir; al Maktabah al Tijariyyah, 1969), hlm. 239.
} 
Salamah al Saqafi, yang telah masuk Islam namun Gailan membawa 10 isterinya, selanjutnya Nabi memerintahkan kepada Gailan untuk memilih 4 orang saja perempuan dari isterinya yang 10 dan ini menjadi dalil dibolehkannya poligami. Selanjutnya Imam Syafi'i berpendapat bahwa bilangan yang ada dalam hadis itu menjadi dalil batasan yang dibolehkan terhadap suami adalah 4 orang isteri apabila suami melakukan poligami. ${ }^{7}$

Dari pendapatnya tersebut maka dapat dikatakan bahwa imam Syafi'i mebolehkan praktik poligami namun demikian imam Syafi'i menetapkan beberapa syarat dalam praktek poligami, yakni mampu berbuat adil kepada para istrinya dan batasan empat perempuan. Adil menurut imam Syafi'i adalah adil secara materi atau in materi. Segi materi seperti nafkah, mewarisi dan pembagian malam. Sedangkan in materi seperti cinta maka sangat sulit dalam mengadilinya karena cinta adalah masalah hati dan masalah hati hanya Allah yang lebih mengetahuinya.

Sedangkan imam Malik adalah pengarang kitab al Muwattha', dan beliau berpendapat bahwa poligami boleh dan laki-laki yang dibolehkan oleh imam Malik untuk berpoligami adalah laki-laki (suami) yang merdeka atau bukan seorang budak. Dan hanya dibolehkan maksimal 4 orang isteri.

Imam Malik ada meriwayatkan sebuah hadis didalam kitabnya al Muwattha', begitu juga an Nasa'i dan Daruquthni kitabnya masing-masing juga ada, yakni:

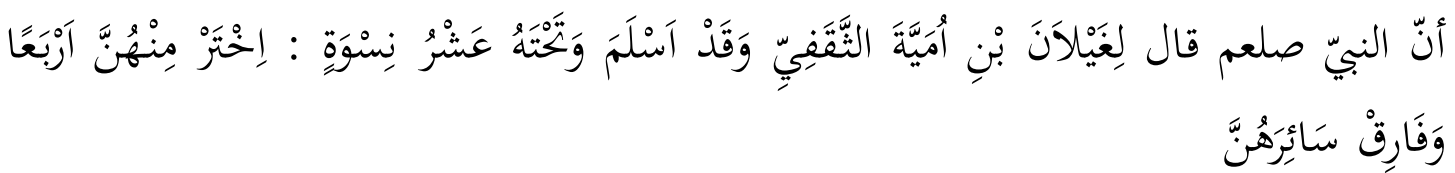

"Bahwa Nabi berkata kepada Ghailan bin Umayyah al Saqafi yang masuk Islam, padahal ia punya sepuluh orang istri. Beliau bersabda kepadanya: Pilihlah empat orang di antara mereka dan ceraikanlah yang lainnya."

Adapun yang dijelaskan oleh hadis ini adalah hadis ini ada setelah turunnya ayat 3 surat an Nisa' kemuadian Nabi memerintahkan memilih 4 dan meninggakan 6 dan lebih dari itu tidak dibolehkan dan terhadap laki-laki tetap memperhatikan batas-batas kemampuan dari diri dan finansial laki-laki tersebut.

Begitu juga dengan imam Hambali menyatakan bahwa poligami boleh dan bats maksimalnya adalah 4 orang isteri dan harus bersikap adil misalnya dalam pembagian giliran para isterinya, selanjutnya tidak boleh lebih memihak kepada salah satu isterinya. Sama juga seperti imam Syafi'i, imam Hambali keadilan yang terdapat pada surat an Nisa' ayat 129 adalah keadilan dalam arti materi, sedangkan keadilan dalam hati mustahil manusia dapat membagi hatinya secara adil. ${ }^{8}$

Ada beberapa kutipan yang dikutip dari imam Hanifah dan Abu Muzhar bin Hammam, dimana ad Dahlawi mengatakan hadis yang disampaikan oleh Gailan bin Salamah ada dasar dibolehkannya poligami dengan 4 batasan isterinya.

7 Asep Nurdin, Hadis-hadis Tentang Poligami (Studi Pemahaman Hadis Berprespektif Gender), (Yogyakarta: UIN Sunan Kalijaga, 2003), hlm. 70.

${ }^{8}$ Ibid., hlm, 74. 
Alam kitab Fiqh 'ala Mazahib Arba'ah, semua pendapat para imam mazhab menyatakan kebolehan (mubah) seorang laki-laki nelakukan poligami atau ta'addud az zaujat. ${ }^{9}$ Dan para imam mazhab juga menambahkan bahwa keadilan yang dimaksud adalah keadilan dalam hal materi bukan keadilan dalam hal hati (cinta) karena keadilan dalam hal hati (cinta) adalah hak Allah dan hanya Allah yang mengetahuinya.

Lebih fenomenal lagi pendapat-pendapat yang disampaikan oleh para mufasirin, seperti imam at Thabari atau ar Razi misalnya, beliau-beliau ini berpendapat bahwa poligami sangat dibolehkan selama bisa berlaku adil. Dan bahkan imam al Jashshah lebih perfec lagi dalam menjelaskan tentang poligami ini, dimana beliau sangat mendalam dalam mengupas poligami maka al Jashshah juga berpendapat bahwa poligami hukumnya boleh. Dan kebolehannya ini ditambah syarat yakni berkemampuan dalam berbuat adil diantara para isteri-isterinya baik dalam hal materi, seperti sanggup menyediakan rumah atau tempat tinggal, memberi nafkah, sanggup membeli pakaian atau sejenisnya. Dan kemudian sanggup memenuhi kebutuhan non material, seperti rasa kasih sayang, cinta kasih atau kecendrungan hati dan semacamnya. Namun al Jashshah menitik beratkan dalah hal hati adalah kemampuan dalam memberi keadilan dalah hal hati dan kasih sayang adalah hal yang berat sekali. ${ }^{10}$

Zamahsyari juga mengeluarkan pandangannya yang lebih ektrim lagi yakni poligami adalah dibolehkan, bahkan jumlah perempuan yang dibolehkan bagi seorang laki-laki yang sanggup berbuat adil bukan hanya 4 namun 9 perempuan atau isteri, yaitu dengan menambahkan 2 tambah 3 dan tambah 4 maka menjadi 9, maka 9 isteri boleh seorang laki-laki menikah dan melakukan praktek poligami.

Ulama klasik, mereka seluruhnya sepakat bahwa Allah telah membolehkan dan mengizinkan kita para laki-laki menikahi 4 orang wanita. Walaupun kesepakatan mereka akan halnya boleh berpoligami, hanya dalam hal memberi nafkah saja yang sanggup namun dalam hal kasih sayang dan cinta tidak dapat adil karena kasih sayang dan cinta tidak bisa diperoleh. Jadi selam dapat dan sanggup berbuat adil dalam memberi nafkah maka dapat diberikan rekomendai untuk berpoligami. Adapun alasannya yakni Nabi pernah berkata bahwa ketidakmampuan berbuat adil adalah dalam hal kebutuhan bathin. ${ }^{11}$

Maka dapat kita katakan bahwa seluruh para ulama sekitar 1300 tahun dala bidang hukum poligami adalah mereka tidak pernah berlainan pendapat, hingga abad ke $18 \mathrm{M}(\mathrm{ke} 13 \mathrm{H})$, semuanya tidak ada berikhtilaf terhadap boleh tidaknya poligami,

\footnotetext{
${ }^{9}$ Abd. al Rahman al Jazairi, al Fiqh 'Ala al Madzahib....., hlm. 206-217.

${ }^{10} \mathrm{Al}$ Jashshash, Ahkam al Qur'an, (Beirut: Dar al Kitab al Islamiya, tt), hlm. 50.

${ }^{11}$ Khoiruddin Nasution, Riba dan Poligami sebuah studi atas Pemikiran Muhammad Abduh, (Yogyakarat: Pustaka Pelajar, 1996), hlm. 99.
} 
namun semuanya sepakat bahwa poligami itu hukumnya mubah (boleh), kerena semuanya itu didasari dengan dalil-dalil yang sudah qath'i atau pasti. ${ }^{12}$

\section{Pendapat Ulama Moderen}

Ada hal yang perlu penulis sampaikan disini sebagai pembanding dari pendapat ulama sebelumnya, yakni poligami menurut pendapat ulama kontemporer. Dalam menyikapi hal ini, sebagian ulama kontemporer ada yang berpendapat, diantaranya:

a. Seorang Sayyid Qutub pernah berkata poligami itu adalah sebuah perbuatan rukhsah, oleh karena poligami itu sebuah rukhsah yang diberikan oleh Tuhan maka apabila poligami itu dilakukan dalam keadaan darurat dan sangat mendesak, maka hukum poligami itu adalah boleh. Dan kebolehan itu dibarengi oleh sifat adil pada diri suami terhadap isteri-isterinya, baik itu adil dalam bidang nafkah, muamalah atau perbagian malam. Dan bila suami itu tidak dapat berbuat adil maka tidak di boleh terhadap seorang laki-laki untuk melakukan poligami dan cukup satu isteri saja. ${ }^{13}$

b. Muhammad Abduh sangat ekstrim dalam menentang akan perbuatan poligami itu, karena Muhammad Abduh menganggap bahwa poligami itu adalah sebuah sumber masalah dan kerusakan di Mesir, dan bahkan dengan tegasnya Muhammad Abduh berkesimpulan bahwa tidak akan dapat di didik masyarakat Mesir itu dengan pendidikan yang sudah bobrok dengan adanya poligami dan dipraktekkan. dengan tegas menyatakan bahwa, adalah tidak mungkin mendidik bangsa Mesir dengan pendidikan yang baik sepanjang poligami yang bobrok ini masih dipraktekkan secara luas. ${ }^{14}$ Dan pernah juga mengelurakan pendapat bahwa asas pernikahan adalah monogani bukan poligami, karena poligami itu hukumnya haram karena dapat menimbulkan dharar (bahaya) seperti terjadi konflik antar isteri dengan anggota keluarganya, oleh karena itu maka poligami boleh karena dharurat. ${ }^{15}$

c. Namun Muhammad Syahrul lain dari pendapat-pendapat diatas, yakni poligami itu boleh hukumnya namu dengan melihat ketangguhan sumber daya dan berkeyakinan dapat adil pada anak-anak yatim. Artinya boleh poligami adalah

\footnotetext{
${ }^{12}$ Abdurrahim Faris Abu Lu’bah, Syawa ib al Tafsir fi al Qarni al Rabi' 'Asyara al Hijri, (Disertasi Doktor), (Beirut : Jamiah Beirut al Islamiyah Kulliyah asy Syariah li Dar al Fatwa Lubnan Idarat al Dirasat al Ulya, 2005), hlm. 360.

${ }^{13}$ Sayyid Qutub, Tafsir fi Dilali al Qur'an, (Beirut: Dar al Kutub al Ilmiyah, 1961), hlm. 236.

${ }^{14}$ Muhammad Rasyid Ridha, Panggilan Islam Terhadap Wanita, (Cairo: Dar ashriyah. tt.), hlm.56.

${ }^{15}$ Rasyid Ridha, Tafsir al Manar, (Beirut: Dar al Fikr, tt.), hlm. 350.
} 
dengan janda yang padanya terdapat anak yatim dan selanjutnya menjadi tanggung jawabnya. ${ }^{16}$

\section{Antara Pemahaman Fiqh Klasik Dan Fiqh Modern}

Secara umum banyak sekali di dalam kitab fiqih klasik yang menyatakan tentang pemberlakukan yang namanya poligami dengan alasan yang sangat kental didalam kitab klasik yakni libido seksual kaum laki-laki (suami) lebih besar adanya ketika isterinya dalam keadaan haid/menstruasi, dengan demikian maka dengan adanya isterinya lebih dari satu maka akan muda para suami dalam menyalurkan seksualnya dan tidak melakukan hal-hal yang dilarang di dalam Islam. Maka pada akhirnya para ulama klasik menetapkan hukum dalam bidang ini kepada bahwa prkatek poligami di bolehkan dalam Islam mengingat secara argumentatif sangat mendukung akan apa yang dijadikan argumen atau alasan dalam hal poligami ini. Namun penetapan hukum ini tetap pada koridornya yakni tetap melihat kepada adanya tuntutan keadilan pada pihak laki-laki dan bila tidak dapat menyanggupi akan keadilan ini maka para laki-laki (suami) dituntut mempunyai isteri cukup satu saja.

Ratna Batar Munti dan Hindun Anisah di dalam bukunya dijelaskan, ketentuan keadilan dalam penentuan terhadap poligami ini ditambahkan akan adanya jaminan terhadap syarat adil yakni misalnya diadakan adanya slip gaji bila ia mempunyai kerja dengan gaji. Dan ini sesuai dengan yang dikatakan dikatakan dalam kitab Fiqh 'Ala al Mazahib al Arba'ah, dimana di dalam kitab tersebut dijelaskan bahwa persyaratan keadilan itu diakur dengan materi, namun keadilan dalam bidang hati atau cinta/kasih sayang tidak dapat diukur. ${ }^{17}$

Para ulama tajdid atau modernis dalam hal poligami ini, mereka memberikan pemahaman yang berbeda dengan para ulama klasik dan juga berbeda dalam memahami atau menafsirkan ayat-ayat tentang poligami ini, seperti, Muhammad Abduh dari Mesir, dimana menurut beliau al qur'an membolehkan poligami karean didasari oleh kondisi pada waktu turunnya dalam kondisi yang mendesak atau darurat. Hal ini di tunjuk oleh qarinah pembolehan praktek poligami ini ditambah oleh syarat yang notabene sangat musykil atau berat dilakukan, yakni adil dalam atrian umum, adil dalam bidang materi atau adil dalam bidang hati/cinta dan kasih sayang sedangkan hal ini sudah sangat jelas tidak mungkin ada pada manusia. Sehingga Muhammad Abduh mengungkapkan bahwa maksud pernikahan akan tercapai yakni pernikahan yang sakinah, mawaddah wa rahmad adalah dengan melakukan pernikahan secara monogami, dan inilah yang dimaksud oleh alqur'an.

\footnotetext{
${ }^{16}$ M. Nashirudin \& Sidik Hasan, Poros-poros Ilahiyah Perempuan Dalam Lipatan Pemikiran Muslim, (Surabaya: Jaring Pena, 2009), hlm. 249.

${ }^{17}$ Ratna Batara Munti \& Hindun Anisah, Posisi Perempuan Dalam Hukum Islam Di Indonesia, (Jakarta: LBH-APIK, 2005), hlm. 105.
} 
Sebagaimana dikatakan oleh dalam formulasi maqasid syariah yang dipopulerkan oleh Jaser Audah, ${ }^{18}$ maka menurut penulis hasil dari prakatek poligami yang dibolehkan dalam Islam adalah dalam keadaan khusus dan bukan dalam keadaan yang bersifat umum sebagaimana yang dikatakan oleh Muhammad Abduh, maka akan berakibat pada Mahkamah Syariah (Pengdilan Agama) sebagai institusi yang dapat dijadikan sebagai pengendali poligami tersebut, yakni dengan dibuatkan peraturan yang mana siap saja yang mau melakukan poligami maka harus mendapatkan surat izin poligami dari isteri pertama yang direkomendasikan oleh Mahkamah Syariah (Pengadilan Agama). Maka poligami dapat dibatasi dan monogami dipopulerkan.

Maka penentuan hukum tentang poligami ini dibolehkan menurut sesuka hati dari si laki-laki atau suaminya namun dengan melihat kepada adakah kemashlahatan yang dicapai oleh perkawinan dengan peligami, karena tujuan dari suatu pernikahan adalah sebagaimana diatas dikatakan yakni tercapainya keluarga yang sakinah mawaddah warrahmah dan kekal sampai kakek-nenek.

Dan lagi segala yang menjadi halangan terwujudnya perkawinan yang digamang-gaman rumahku adalah syurgaku, maka harus segera dihilangkan, bila tidak hilang, maka sekurang-kurannya dikurangi. Ini sejalan dengan kaidah usul:

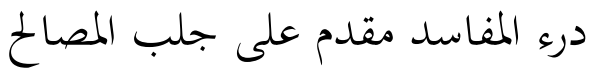

Menghindari kerusakan atau kesusahan itu maka harus di dahulukan dari pada mengambil manfaat (kemaslahatan). ${ }^{19}$

Pada era modern ini banyak sekali muncul bermacam-macam pendapat bahkan sudah menjadi polemik terhadap permasalahan poligami ini, ada diantara mereka yang mendukung dan ada juga yang menolak terhadap pandangan-pandangan kaum liberalis dan feminis dalam mensikapi poligami.

Ada beberapa pandangan para feminisliberal, yakni pandangan mereka tentang poligami yang dengan lantang mereka menyampaikan statemen dan mereka anggap sebagai subhat-subhat yang ada dalam poligami, yakni diantaranya:

1. Abdullah Ahmed Na'im, orang yang berani mengatakan bahwa praktek poligami itu adalah sebuah diskriminasi agama terhadap hukum keluarga dan perdata, dengan argumentasi yang dia buat bahwa seorang laki-laki lagi muslim boleh kawin walau secara bersamaan sampai empat orang perempuan, namun seorang perempuan hanya dibolehkan kawin dengan seorang laki-laki saja dan bahkan haram bila perempuan mengawini dua atau lebih laki-laki. ${ }^{20}$

2. Mahmud Muhammad Thaha berpendapat dengan pendapat yang dipandang sebagai pendapat yang berani yakni poligami itu bukanlah ajaran pada prinsip

18 Jaser 'Audah, Maqasid al Syariah as Philosophy of Islamic Law: A System Aproach, (London: The International Institute of Islamic Though, 2007), hlm. xxv.

${ }^{19}$ Ahmad Rofiq, Hukum Islam Di Indonesia, (Jakarta: PT Raja Grafindo Persada, 1998), hlm 176.

\footnotetext{
${ }^{20}$ Abdullah Ahmed an Na'im, Dekonstruksi Syari'ah, (Jogjakarta: LkiS, 1997), hlm. 338.
} 
dasar Islam. Beliau berpendapat demikian dikarena secara prinsip Islam adalah dalam permasalahan perkawinan antara laki-laki dengan perempuan adalah setara. Secara menyeluruh laki-laki itu adalah milik perempuan tanpa ada mahar dan diantara keduanya tiada perceraian. ${ }^{21}$

Adapun pendapat lain yang berlainan dengan pendapat diatas, yaitu pendapat sepakat terhadap pendapat yang menyatakan boleh poligami dalam Islam dengan argumetatif dan seorang laki-laki itu banyak sekali yang menjadi motivasi baginya sehingga termotivasi untuk melakukan poligami. Namun selama tidak menyimpang dorongan itu dari syariat Islam, maka tidak mengapa dan tidak ada larangan untuk melakukan poligami tersebut.

Pertimbangan kaum laki-laki mau melakukan poligami antara lain: a. Faktor biologis tinggi, seperti: Isteri dalam keadaan sakit, libido seknya yang tinggi, rutinitas alami pada diri wanita, masa subur kaum laki-laki lebih lama. b. Faktor internal rumah tangga; misalnya: isteri mandul, tubuhnya lemah dan isterinya memiliki kepribadian yang buruk.

\section{Rancangan Qanun (Raqan) Poligami Di Aceh}

Aceh salah daerah yang diberikan wewenang merancang dan membuat qanun dan dapat diterapkan sebagai syari'ah untuk masyarakat Aceh. Dengan adanya wewenang yang diberikan maka Aceh merancanglah sebuah qanun (Raqan/Perda) tentang hukum keluarga dan didalamnya membahas tentang poligami.

Dalam Raqan tersebut pada bab VIII diatur adanya tentang poligami yakni ber-isteri lebih dari satu. Dalam bab tersebut diatur persayaratan-persyaratan sampai permasalahan izin dari isteri pertama dan semuanya terkumpul dalam lima pasal. Dalam pasal 46 dijelaskan tentang kriteria-kriteria suami yang bagaimana yang dapat atau dibolehkan untuk melakukan poligami yakni suami yang mempunyai kesiapan baik lahir maupun bathin. Adapun argumentatif dari dirancangnya qanun ini hanya dengan satu tujuan yakni melindungi kaum perempuan dari pernikahan sirri dengan menata hak yang sama antara sesama isteri dan anak-anaknya baik dari isteri pertama atau kedua, ketiga dan keempat.

Sama juga dengan peraturan yang tersebut di dalam KHI yakni seorang suami yang hendak melakukan pernikahan dengan perempuan yang lain dalam arti kata isteri kedua hingga keempat, haruslah mendapat izin terlebih dahulu dari Mahkamah Syar'iah, sebagaimana yang tersebut dalam Raqan pasal 47 yang mewajibkan izin dari Mahkamah Syar'iyah terlebih dahulu.

Namun bila tanpa mendapatkan izin dari Mahkamah Syar'iyah maka pernikahan tersebut tidak mempunyai kekuatan hukum, sehingga bila terjadi konflik diatar keduanya, tidak dapatlah diselesaikan secara hukum Mahkamah Syar'iyah.

\footnotetext{
${ }^{21}$ Mahmud Muhammad Thaha, Arus Balik Syari'ah, (Jogjakarta: LkiS, 2003), hlm. 167.
} 
Mahkamah Syar'iyah dalam memberikan izin tidaklah secara sembarangan, karena persoalan ini adalah persoalan yang sangat sensitif terlebih bagi pihak isteri/perempuan. Maka Mahkamah Syar'iyah menetapkan syarat-syarat yang harus dipenuhi oleh seorang suami dan persoalan ini diatur dalam pasal 48, diantaranya: istri tidak dapat menjalankan kewajiban sebagaimana diatur dalam Qanun ini; atau istri mendapat cacat badan atau penyakit yang tidak dapat disembuhkan yang dibuktikan dengan keterangan dari dokter ahli.; atau Istri tidak dapat melahirkan keturunan yang dibuktikan dengan keterangan dari dokter ahli.

Begitu juga dalam pasal 49 Raqan ini menambahkan tentang syarat-syarat yang harus dilengkapi oleh sorang suami, ada persetujuan daripada isteri atau isteriisterinya, ada kemampuan suami dalam memenuhi sandang dan pangan isteri-isteri atau anak-anaknya.

\section{Penutup}

Dalam pandangan ulama fiqh klasik (fiqh Mazhab) mengatakan poligami hukumnya diboleh dengan ketentuan-ketentuan yang telah disebutkan diatas. Sedangkan pada ulama modern permasalahan poligami ini muncul pada era modern seperti Pro dan kontra terhadap poligami, sebagian kelompok menolak poligami dan mengganggap bukan syari'ah Islam dengan mengajukan berbagai argumentasi yang menguatkan pendapat mereka seperti Abdullah Ahmed Na'im dari Sudan dan Mahmud Muhammad Thaha dan lainnya. Dan sebagaian kelompok lainnya mendukung poligami sebagai syari'ah yang dapat dilaksanakan apabila memenuhi syarat dan ketentuanya.

Dalam rancangan qanun syari'ah Islam Aceh tentang aturan poligami pada dasarnya antara UU Perkawinan tahun 1974 dan Peraturan Pemerintah Nomor 9 tahun 1975 dan Kompilasi Hukum Islam tidak begitu bedan satu sama lainnya, sehingga masalah poligami di Aceh dalam bingkai syariat Islam tidaklah bertentangan dengan hukum Islam pada umumnya dan hukum posistif di Indonesia, karena tetap mengedepankan nilai-nilai kemashlahatan dan menolak mafsadah (kerusakan dan kehancuran). Wallahu a'lam.

\section{DAFTAR PUSTAKA}

Al Jashshash. Ahkam al Qur'an, Beirut: Dar al Kitab al Islamiya, tt. al Jazairi, Abd. al Rahman. al Fiqh 'ala al Madzahib al 'Arba'ah, Mesir; al Maktabah al Tijariyyah, 1969.

an Na'im, Abdullah Ahmed. Dekonstruksi Syari'ah, Jogjakarta: LkiS, 1997. Audah, Jaser. 'Maqasid al Syariah as Philosophy of Islamic Law: A System Aproach, London: The International Institute of Islamic Though, 2007. 
Hamid, Al qamar. Hukum Islam Alternative Terhadap Masalah Fiqh Kontemporer, Jakarta: Restu Ilahi, 2005.

Kuzani, Achmad. Nikah Sebagai Perikatan, Jakarta: PT Raja Grafindo, 1995.

Lu'bah, Abdurrahim Faris Abu. Syawaib al Tafsir fi al Qarni al Rabi' 'Asyara al Hijri, (Disertasi Doktor), Beirut : Jamiah Beirut al Islamiyah Kulliyah asy Syariah li Dar al Fatwa Lubnan Idarat al Dirasat al Ulya, 2005

Munti, Ratna Batara \& Hindun Anisah. Posisi Perempuan Dalam Hukum Islam Di Indonesia, Jakarta: LBH-APIK, 2005Sohari Sahrani Tihami, Fikh Munakahat: Kajian Fiqh Nikah Lengkap. Jakarta: Rajawali Pers, 2010.

Nashirudin, M. \& Sidik Hasan. Poros-poros Ilahiyah Perempuan Dalam Lipatan Pemikiran Muslim, Surabaya: Jaring Pena, 2009.

Nasution, Khoiruddin. Riba dan Poligami sebuah studi atas Pemikiran Muhammad Abduh, Yogyakarat: Pustaka Pelajar, 1996.

Nurdin, Asep. Hadis-hadis Tentang Poligami (Studi Pemahaman Hadis Berprespektif Gender), Yogyakarta: UIN Sunan Kalijaga, 2003.

Penulis, Team. Departemen Pendidikan dan Kebudayaan RI. Kamus Besar Bahasa Indonesia, Jakarta: Balai Pustaka.

Penulis, Team. Ensiklopedi Indonesia, Jilid 5, Jakarta: Ikhtiar Baru Van Hoeve.

Qutub, Sayyid. Tafsir fi Dilali al Qur'an, Beirut: Dar al Kutub al Ilmiyah, 1961.

Ridha, Muhammad Rasyid. Panggilan Islam Terhadap Wanita, Cairo: Dar ashriyah. tt.

Ridha, Rasyid. Tafsir al Manar, Beirut: Dar al Fikr, tt.

Rofiq, Ahmad. Hukum Islam Di Indonesia, Jakarta: PT Raja Grafindo Persada, 1998.

Thaha, Mahmud Muhammad. Arus Balik Syari'ah, Jogjakarta: LkiS, 2003. 